\title{
PENERAPAN KETENTUAN PASAL 21 AYAT (3) UUPA TENTANG KEPEMILIKAN TANAH BAGI WNI DALAM PERKAWINAN CAMPURAN
}

\author{
IMPLEMENTATION OF ARTICLE 21 SUBSECTION 3 OF AGRARIAN \\ LAW TO MIX MARRIAGE
}

\author{
Sayaman Harahap \\ Magister Kenotariatan Universitas Mataram \\ email : sayaman_h@yahoo.com \\ Naskah diterima : 18/07/2016; revisi : 19/12/2016; disetujui : 30/12/2016
}

\begin{abstract}
Indonesian citizen, who marry foreign citizen, could not hold ownership right to land in Indonesia unless he or she has pre-marriage agreement. The pre-marriage agreement would free the Indonesian citizen, who marry foreign citizen, from the provision of article 21 subsection 3 of the Agrarian Law. However, the fact show that many Indonesian citizens, who marry foreign citizens, owing to ignorance hold right ownership to land although they do not have pre-marriage agreement. This research is aimed at analysing the implementation of article 20 subsection 3 of Agrarian Law. This research is also conducted to provide thought for society, institution concerned and students for knowledge development. Method used in this research is normative-empirical legal method with law, conceptual and sociological approach. Result of this research shows that implementation of article 21 subsection 3 of the Agrarian Law, which state that Indonesian citizen who marry foreign citizen shall waive his or her ownership right during the period of one year, in fact is not put into practice effectively.
\end{abstract}

Keyword: implementation of the provision of article 21 subsection 3 of the Agrarian Law

Abstrak

Warga Negara Indonesia yang menikah dengan Warga Negara Asing tidak bisa memiliki hak atas tanah kecuali dia memiliki perjanjian pra-nikah. Perjanjian pra-nikah akan membebaskan warga negara Indonesia yang menikah dengan warga negara asing, dari ketentuan Pasal 21 ayat (3) UUPA. Bagaimanapun juga, fakta menunjukkan bahwa banyak warga negara Indonesia yang melakukan perkawinan dengan WNA mengabaikan kepemilikan hak atas tanah meskipun mereka tidak memiliki perjanjian pra-nikah. Penelitian ini bertujuan untuk menganalisis implementasi Pasal 20 ayat (3) UUPA. Penelitian ini juga dilakukan untuk menyediakan pemikiran bagi masayarkat, instansi yang mempelajari atau perhatian untuk pembangunan ilmu pengetahuan. metode yang digunakan dalam penelitian ini adalah penelitian hukum normatif-empiris. Hasil penelitian ini menunjukkan bahwa implementasi dari Pasl 21 ayat (3) UUPA, di mana negara warga negara Indonesia yang menikah dengan orang asing harus melepaskan kepemilikan hak atas tanahnya dalam jangka waktu satu tahun, dalam peraktek hal ini tidak efektif.

Kata Kunci: Pemilikan, Tanah, WNA, Perkawinan Campuran.

\section{PENDAHULUAN}

TANAH MERUPAKAn karunia Tuhan Yang

Maha Esa bagi bangsa Indonesia yang dikuasai oleh negara untuk kepentingan dan kelangsungan hidup bangsa dalam mencapai kemakmuran rakyat secara adil dan merata. Tanah adalah salah satu kebutuhan dasar manusia, terutama untuk tempat tinggal suatu keluarga. Peranan tanah sangat penting sebagai bagian dari kebutuhan yang sangat pokok bagi setiap 
orang, tanah di sini dimaknai secara filosofis yang cenderung diartikan sebagai land dan bukan soil. ${ }^{1}$

Secara filosofis, makna tanah tercantum dalam Undang-Undang Dasar 1945, Pasal 33 ayat ( 3 ), menyatakan bahwa :2

"Bumi dan air dan kekayaan alam yang terkandung didalamnya dikuasai oleh Negara dan dipergunakan untuk sebesarbesarnya kemakmuran rakyat".

Ada dua pengertian mengenai penguasaan tanah dalam Pasal 33 ayat (3) UUD 1945, yang meliputi :

1. Penguasaan negara:dan

\section{Filosofi penguasaan negara.}

Penguasaan negara atas tanah tidak berarti "dimiliki", akan tetapi adalah pengertian, yang memberi wewenang kepada negara, sebagai organisasi kekuasaan dari bangsa Indonesia itu, untuk pada tingkatan yang tertinggi $:^{3}$

1. Mengatur dan menyelenggarakan peruntukan, penggunaan, persediaan, dan pemeliharaannya;

2. menentukan dan mengatur hak-hak yang dapat dipunyai atas (bagian dari) bumi, air, dan ruang angkasa itu; dan

3. menentukan dan mengatur hubunganhubungan antara orang-orang dan perbuatan hukum yang mengenai bumi, air, dan ruang angkasa.

Sementara itu filosofi penguasaan negara atas tanah tercantum dalam penjelasan UUPA, bahwa :

"Meletakkan dasar-dasar bagi penyusunan hukum agraria nasional, yang akan merupakan alat untuk membawakan ke-

\footnotetext{
Aa Sholah, http://www.caragampang. com/2014/08/pengertian-dan-definisi-tanah-menurut. html\# diunduh pada tanggal 29 Februari 2016.

2 Salim HS, Teknik Pembuatan Akta (PPAT), PT Raja Grafindo Persada, Jakarta, 2016, hlm. 23.

${ }^{3}$ Ibid, hlm. 23.
}

makmuran, kebahagiaan dan keadilan bagi negara dan rakyat, terutama rakyat tani, dalam rangka masyarakat yang adil dan makmur ".

Pengaturan lebih lanjut dari ketentuan tersebut di atur dengan Undang-Undang Nomor 5 Tahun 1960 Tentang Peraturan Dasar-Dasar Pokok Agraria (UUPA) 1960, Lembaran Negara Nomor 104 Tahun 1960 No 2043. Salah satu prinsip yang dianut adalah prinsip Nasionalitas.

Prinsip Nasionalitas tercermin dalam ketentuan Pasal 1 ayat (2) UUPA yang menentukan bahwa seluruh wilayah Indonesia adalah kesatuan tanah air dari seluruh rakyat Indonesia yang bersatu sebagai bangsa Indonesia. Seluruh bumi air dan ruang angkasa termasuk kekayaan alam yang terkandung di dalamnya dalam wilayah Republik Indonesia sebagai karunia Tuhan Yang Maha Esa adalah bumi, air, dan ruang angkasa bangsa Indonesia dan merupakan kekayaan nasional. Bahwa, "hubungan antara bangsa Indonesia dan bumi air serta ruang angkasa adalah hubungan yang sangat abadi." 4 Selanjutnya dalam Pasal 1 ayat (3) ditentukan bahwa hubungan antara bangsa Indonesia dan bumi, air serta ruang angkasa termaksud dalam ayat (2) Pasal ini adalah hubungan yang bersifat abadi. Oleh karena itu, maka didalam ketentuan Pasal 21 ayat (1) UUPA yang menyatakan bahwa," hanya warga Negara Indonesia dapat mempunyai hak milik."

Prinsip ini menentukan bahwa hanya WNI yang dapat mempunyai hubungan sepenuhnya dengan tanah. Hal ini diatur untuk memperoleh kepastian hukum dan perlindungan hukum bagi rakyat banyak akan hak atas tanahnya. Tanah adalah kebutuhan dasar untuk tinggal suatu keluarga untuk hidup bersama antara seorang laki laki dan perempuan sebagai

${ }^{4}$ H.M. Arba , Hukum Agraria Indonesia, Sinar Grafika, Jakarta, 2015, hlm. 20. 
pasangan suami istri dan lazimnya disebut sebagai sebuah perkawinan.

Filosofis pengertian perkawinan, menurut ketentuan Pasal 1 Undang-Undang Nomor 1 Tahun 1974 tentang perkawinan adalah;

"Ikatan lahir batin antara seorang pria dengan seorang wanita sebagai suamiisteri dengan tujuan membentuk keluarga (rumah tangga) yang bahagia dan kekal berdasarkan Ketuhanan Yang Maha Esa".

Sahnya perkawinan, sebagaimana diuraikan ada Pasal 29 ayat (1) UndangUndang Nomor 1 Tahun 1974 yang menentukan, bahwa: "Perkawinan adalah sah apabila dilakukan menurut hukum masingmasing agamanya dan kepercayaannya itu'. Ini berarti bahwa jika suatu perkawinan telah memenuhi syarat dan rukun nikah sudah dilaksanakan (bagi umat Islam) atau pendeta/pastur telah melaksanakan pemberkatan atau ritual lainnya (bagi yang non muslim), maka perkawinan tersebut adalah sah, terutama di mata agama dan kepercayaan masyarakat.

Dengan perkembangan jaman yang semakin modern saatini, banyak masyarakat kita yang menikah dengan Warga Negara Asing (WNA). Proses perkenalan yang paling trend dengan warga negara asing melalui teknologi seperti melalui chatting, facebook, twitter, dan lain sebagainya.

Secara sosiologi masyarakat yang melakukan perkawinan campuran mempunyai banyak motif dan tujuan yang tidak baik, seperti Faktor investasi, ekonomi dan faktor keturunan. Hal ini kadang tidak dipahami/diketahui pihak WNI pelaku perkawinan campuran dengan WNA, sangat merugikan WNI dari segi aturan hukum ketentuan isi Pasal 21 ayat (3) UUPA, karena sebagian tidak didasari atas dasar cinta. Ketentuan di atas sangat bertentangan dengan harapan dan penerapan UU No $1 / 74$ tentang perkawinan dan Pasal 21 ayat (3) UUPA.

Undang-undang Dasar Negara Republik Indonesia 1945 (UUD RI 1945) Pasal 28 B ayat (1) menentukan bahwa :

"Setiap orang berhak membentuk keluarga dan melanjutkan keturunan melalui perkawinan yang sah. Perkawinan bersifat universal dan tidak dibatasi oleh warna kulit, ras dan kewarganegaraan".

Di Indonesia, perkawinan antara seorang Warga Negara Indonesia (WNI) dengan Warga Negara Asing (WNA) merupakan perkawinan campuran. Apabila perkawinan dilakukan antara dua orang warga Negara Indonesia yang berbeda agama, bukan termasuk dalam perkawinan campuran, melainkan perkawinan beda agama.

Pengertian Perkawinan campuran dijumpai dalam Pasal 57 UU Perkawinan nomor 1 tahun 1974, menentukan bahwa yang dimaksud dengan perkawinan campuran dalam undang-undang ini ialah "perkawinan antara dua orang yang di Indonesia tunduk pada hukum yang berlainan, karena perbedaan kewarganegaraan dan salah satu pihak berkewarganegaraan Indonesia." Perkawinan termasuk perkawinan campuran apabila perkawinan tersebut dilangsungkan antara dua orang yang mempunyai kewarganegaraan berbeda, satu di antaranya berkewarganegaraan Indonesia.

Perkawinan campuran ini tidak membedakan hak-hak pria dan wanita sesuai dengan konvensi CEDAW (Convention on the Elimimation of all Forms of Discrimination Against Women) yang menegaskan penghapusan diskriminasi wanita dan melindungi hak wanita. Sesuai dengan pasal $2 C E D A W$ butir (a) menetapkan kaidah persamaan wanita dengan pria wajib dicantumkan dalam Undang-Undang Dasar dan Perundang- 
undangan Negara-Negara Peserta, kecuali kalau itu sudah dilaksanakan. ${ }^{5}$

Berdasarkan (UU No.7/1984), Konvensi perlindungan kawin (CEDAW). Pasal 16 ayat (1) huruf :

a. Bahwamenggariskanhakwanitamemiliki suami secara bebas dan haknya memasuki ikatan perkawinan hanya dengan persetujuan yang bebas sepenuhnya.

b. Bahwa mensyaratkan hak dan tanggung jawab yang sama dalam perkawinan maupun putusnya.

c. Bahwa mensyaratkan hak dan tanggung jawabyangsamasebagaiorangtua,terlepas dari status kawin mereka, dalam urusan yang berhubungan dengan anak mereka namun demikian dalam semua kasus, kepentingan anak akan diutamakan.

d. Bahwa mensyaratkan hak yang sama untuk kedua suami dan isteri bertalian dengan harta benda.

Perkawinan campuran selama telah dilangsungkan sesuai dengan UU Perkawinan dan perkawinan telah dicatatkan, maka perkawinan tersebut adalah sah dan mengikat kedua belah pihak, namun permasalahannya timbul berkaitan dengan harta benda yang diperoleh selama perkawinan. Perkawinan campuran akan menimbulkan akibat (harta bersama) pada harta perkawinan, terutama terkait dengan harta bersama antara suami-istri yang melangsungkan perkawinan campuran tersebut.

Pengaturan terhadap harta kekayaan dalam perkawinan (harta bersama) diatur pada Pasal 35 sampai Pasal 37 UndangUndang Perkawinan Nomor 1 Tahun 1974. Harta bersama dalam perkawinan dapat dibedakan ke dalam benda bergerak berupa (mobil, perhiasan, lukisan, emas batangan dan sebagainya) dan dapat pula berupa benda tidak bergerak berupa (tanah).

\footnotetext{
5 www.http:donyminang.blogspot.co.id/2011/11/ dony.html. diunduh pada tanggal 2 April 2016.
}

Dengan demikian harta apa saja baik yang (berwujud atau tidak berwujud), yang diperoleh terhitung sejak saat dilangsungkan (akad nikah) sampai pada saat perkawinan terputus, baik oleh karena salah satu pihak meninggal dunia maupun karena perceraian, maka seluruh harta tersebut dengan sendirinya menurut hukum menjadi harta bersama.

Dari penjelasan diatas, dengan adanya perkawinan, harta itu tidak bersatu tetap dibedakan antara harta asal yang diperoleh berupa hadiah, warisan, hibah tetap di bawah penguasaan masing-masing dan harta yang di dapat selama perkawinan menjadi harta bersama .

Selanjutnya persoalan mengenai perkawinan campuran dikaitkan dengan dengan menurut UU No 12/2006 tentang Kewarganegaraan, dalam Pasal 26 ayat (1) dan (2). Berdasarkan penjelasan pasal-pasal di atas maka jika seorang WNI yang menikah dengan WNA maka akan kehilangan kewarganegaraan nya, berdasarkan hukum negara dari WNA tersebut sehingga mengakibatkan WNI tersebut kehilangan kewarganegaraan nya seperti hak-hak atas tanah di Indonesia (hak milik salah satunya) maka berlakulah ketentuan Pasal 21 ayat (3) UUPA, kecuali jika dia mengajukan pernyataan untuk tetap menjadi WNI ( Pasal 58) UUPA.

Konsep dan pengertian mengenai harta bersama dalam Pasal 35 ayat 1 UU No 1/74 tentang perkawinan jika dibandingkan dengan pengertian harta bersama dalam KUHPerdata terdapat perbedaan yang mendasar sesuai Pasal 119 bahwa, :

"Mulai saat perkawinan dilangsungkan, demi hukum berlakulah persatuan bulat antara harta kekayaan suami dan istri, sekedar mengenai itu dengan perjanjian kawin tidak diadakan ketentuan lain. Persatuan itu sepanjang perkawinan tak boleh ditiadakan atau diubah dengan sesuatu 
persetujuan antara suami dan istri."

Berdasarkan Pasal 35 ayat (1) UndangUndang No 1 tahun 1974 tentang Perkawinan, menentukan bahwa: harta benda yang diperoleh selama perkawinan berlangsung menjadi harta bersama dan harta bawaan di bawah penguasaan masing-masing. Oleh karena itu, secara hukum maka harta yang diperoleh selama perkawinan berlangsung termasuk dalam perkawinan campuran antara seorang WNI dengan WNA, apakah itu merupakan harta (benda bergerak dan tidak bergerak) berupa tanah menjadi harta bersama. Sehingga akibat hukum perkawinan campuran antara WNA dan WNI terhadap harta bersama, maka seorang WNA secara hukum dapat memiliki dan menguasai tanah di Indonesia melalui perkawinan campuran. Pada bagian lain, Pasal 21 ayat (1) UUPA, menentukan bahwa "Hanya warga negara Indonesia dapat mempunyai hak milik". Untuk memenuhi prinsip dasar dalam ketentuan Pasal 21 ayat (1) tersebut terhadap WNI pelaku perkawinan campuran dijelaskan dalam Pasal 21 ayat (3) UUPA.

Dengan demikian harta kekayaan dalam perkawinan menurut KUHPerdata, dengan adanya perkawinan, maka sejak saat itu harta kekayaan baik harta bawaan berupa hadiah, hibah, warisan menjadi harta bersama suami/isteri (terjadi percampuran harta) kecuali ditentukan lain dengan perjanjian perkawinan.

Berdasarkan beberapa ketentuan, baik ketentuan mengenai perkawinan campuran dalam UU No. 1 tahun 1974, ketentuan mengenai perkawinan campuran dalam UU No. 12 tahun 2006 tentang kewarganegaraan, seorang WNI yang melakukan perkawinan campuran dengan WNA dapat kehilangan haknya sebagai Warga Negara Indonesia. Akibat hukum berikutnya terhadap WNI yang melakukan perkawinan campuran dengan WNA tersebut, tidak bisa sepenuhnya mendapatkan Hak Milik atas tanah, karena berdasarkan Pasal 21 ayat (1), jo. Pasal 21 ayat (3) UUPA, diwajibkan untuk melepaskan hak miliknya dalam waktu satu tahun sejak kehilangan kewarganegaraan. Demikian pula, bagi WNI yang melakukan perkawinan campuran dengan WNA, dan mereka sama-sama mempertahankan status kewarganegaraan nya masing-masing, maka suami/istri yang berstatus WNA tidak dapat memperoleh hak milik atas tanah dari perkawinan (Harta Bersama). Padahal di sisi lain, Pasal 35 UU No. 1 tahun 1974 tentang Perkawinan, menentukan bahwa "Harta benda diperoleh selama perkawinan berlangsung menjadi harta bersama antara suami istri". Beberapa persoalan di atas, memberikan gambaran bahwa terjadi pertentangan norma (conflict of norm) antara ketentuan Pasal 35 UU No. 1 Tahun 1974 dengan ketentuan Pasal 21 ayat (1) UUPA. Yang menyatakan bahwa:

"Hanya orang Indonesia yang boleh memiliki hak atas tanah di Indonesia"

Selanjutnya seperti yang tercantum dalam Pasal 29 ayat (1) Undang-Undang Nomor 1 Tahun 1974 Tentang Perkawinan dinyatakan tentang perjanjian kawin. Apabila WNA yang melakukan pekawinan campuran dengan WNI masuk agama Islam maka perjanjian kawin tersebut dilakukan secara Islam dengan membuat akta di bawah tangan. Sedangkan perjanjian kawin secara perdata dibuat secara notariil yang disahkan oleh pegawai pencatat perkawinan, yaitu baik di Kantor Urusan Agama (KUA) maupun Kantor Catatan Sipil (Pasal 29 UU No. 1 tahun 1974 tentang Perkawinan). ${ }^{6}$ Sehingga berdasarkan uraian diatas mendorong penulis untuk mengangkat masalah ini dalam suatu kajian ilmiah. Berdasarkan uraian latar belakang diatas, maka ada beberapa hal yang diangkat

\footnotetext{
${ }^{6}$ Irma Devita Purnamasari, Kiat-kiat Cerdas, Mudah dan Bijak Memahami Masalah Hukum Waris, Mizan Pustaka, Bandung, 2014
} 
sebagai rumusan masalah dan akan dicari penyelesaiannya secara ilmiah. Adapun rumusan masalah tersebut yaitu : 1 . Bagaimanakah akibat hukum perkawinan campuran terhadap kepemilikan hak atas tanah (harta bersama) ? dan 2. Bagaimanakah efektifitas penerapan ketentuan Pasal 21 ayat (3) UUPA dalam perkawinan campuran khususnya yang berkaitan dengan kepemilikan hak atas tanah (harta bersama)?

Guna untuk menjelaskan permasalahan di atas maka terdapat beberapa teori terkait dengan tema yang diangkat, untuk mengurai permasalahan-permasalahan yang diangkat yaitu :

\section{Teori Kepastian Hukum}

Akibat hukum perkawinan campuran terhadap kepemilikan hak atas tanah terhadap harta bersama dari percampuran harta. Sesuai Pasal 21 ayat (3) UUPA, jelas disebutkan bahwa, WNI bisa memiliki hak milik atas tanah, atas namanya sendiri dengan ketentuan lain mempunyai perjanjian kawin. Hal ini untuk memberikan kepastian hukum terhadap kepemilikan hak milik atas tanah oleh WNI perkawinan campuran di Indonesia karena berdasarkan pasal ini pihak WNI perkawinan campuran bisa kehilangan haknya untuk memiliki hak milik atas tanah akibat perkawinan campuran juga kehilangan kewarganegaraannya dari suami/istri WNA.

Dalam praktiknya, apabila kepastian hukum dikaitkan dengan keadilan hukum, maka akan kerap kali tidak sejalan satu sama lain. Adapun hal ini dikarenakan di satu sisi tidak jarang kepastian hukum mengabaikan prinsip-prinsip keadilan hukum, sebaliknya tidak jarang pula keadilan hukum mengabaikan prinsip-prinsip kepastian hukum. Apabila dalam praktiknya terjadi pertentangan antara kepastian hukum dan keadilan hukum, maka keadilan hukum yang harus diutamakan. Alasannya adalah, bahwa keadilan hukum pada umumnya lahir dari hati nurani pemberi keadilan, sedangkan kepastian hukum lahir dari suatu yang konkrit.

\section{Teori Perlindungan Hukum}

Akibat hukum perkawinan campuran terhadap harta bersama kepemilikan benda tidak bergerak berupa tanah. Sesuai Pasal 21 ayat (3) UUPA, jelas disebutkan bahwa, WNI bisa memiliki hak milik atas tanah, atas namanya sendiri dengan ketentuan lain mempunyai perjanjian kawin. Hal ini untuk memberikan perlindungan hukum terhadap kepemilikan hak milik atas tanah oleh WNI perkawinan campuran di Indonesia karena berdasarkan pasal ini pihak WNI perkawinan campuran bisa kehilangan haknya untuk memiliki hak milik atas tanah akibat perkawinan campuran juga kehilangan kewarganegaraan nya.

Menurut Satjipto Raharjo mendefinisi$\operatorname{kan}^{7}$ perlindungan hukum adalah :

"Memberikan pengayoman kepada hak asasi manusia yang dirugikan orang lain dan perlindungan tersebut diberikan kepada masyarakat agar mereka dapat menikmati semua hak-hak yang diberikan oleh hukum."

Menurut Muktie A. Fadjar menyatakan bahwa perlindungan hukum8 adalah:

"Penyempitan arti dari perlindungan, dalam hal ini hanya perlindungan oleh hukum saja. Perlindungan yang diberikan oleh hukum, terkait pula dengan adanya hak dan kewajiban, dalam hal ini yang dimiliki oleh manusia sebagai subyek hukum dalam interaksinya dengan sesama manusia serta lingkungannya. Sebagai subyek hukum manusia memiliki hak dan

${ }^{7}$ Aristoteles dalam Satjipto Rahardjo, Ilmu Hukum, Citra Aditya Bakti, Bandung, 2000. hlm. 23

$8 \mathrm{Hukum} / /$ blogspot www.tesishukum.com, Perlindungan Hukum menurut para ahli, diunduh pada tanggal 22 Februari 2015 pukul 12.00 WITA 
kewajiban untuk melakukan suatu tindakan hukum".

Dalam menjalankan dan memberikan perlindungan hukum dibutuhkannya suatu tempat atau wadah dalam pelaksanaannya yang sering disebut dengan sarana perlindungan hukum. Sarana perlindungan hukum dibagi menjadi dua macam yang dapat dipahami, sebagai berikut ${ }^{9}$ :

1. Sarana Perlindungan Hukum Preventif, yaitu subyek hukum diberikan kesempatanuntukmengajukankeberatan atau pendapatnya sebelum suatu keputusan pemerintah mendapat yang definitif. Tujuannya adalah mencegah terjadinya sengketa.

2. Sarana Perlindungan Hukum Represif, yaitu bertujuan untuk menyelesaikan sengketa. Penanganan perlindungan hukum oleh Pengadilan Umum dan Peradilan Administrasi di Indonesia termasuk kategori perlindungan hukum ini.Prinsipperlindunganhukumterhadap tindakan pemerintah bertumpu dan bersumberdarikonseptentangpengakuan dan perlindungan terhadap hak asasi manusia.

\section{Teori Efektifitas hukum}

Hans Kalsen menyajikan definisi tentang efektifitas hukum. Efektifitas hukum adalah $^{10}$ :

"Apakah orang-orang pada kenyataannya berbuat menurut sesuatu cara untuk menghindari sanksi yang diancamkan oleh norma hukum atau bukan, dan apakah sanksi tersebut benar-benar dilaksanakan bila syaratnya terpenuhi atau tidak terpenuhi."

${ }^{9}$ Philipus M. Hadjon, Perlindungan Hukum Bagi Rakyak Indonesia, PT. Bina Ilmu, Surabaya, 1987, hlm. 2, dalam Salim, HS \& Erlies Septiana Nurbani. ed. Penerapan Teori Hukum Pada Penelitian Tesis dan Disertasi. Penerbit Raja Grafindo Persada, Jakarta, 2013.

${ }^{10}$ Hans Kelsen, Teori Umum Tentang Hukum dan Negara, Nusa Media, Bandung, 2006, hlm. 39
Konsep efektifitas dalam definisi Hans Kelsen difokuskan pada subjek dan sanksi. Subjek yang melaksanakannya, yaitu orangorang atau badan hukum. Orang-orang tersebut harus melaksanakan hukum sesuai dengan bunyinya norma hukum. Bagi orangorang yang dikenai sanksi hukum, maka sanksi hukum benar-benar dilaksanakan atau tidak ${ }^{11}$.

Penelitian ini menggunakan metode penelitian hukum normatif empiris. Penelitian normatif yaitu untuk mengkaji dan memahami norma-norma/kaidahkaidah, dimana bahan untuk mengawali sebagai dasar sudut pandang dan kerangka berfikir seorang peneliti untuk melakukan analisis. Penelitian empiris (socio legal) adalah pendekatan hukum untuk mengkaji gejala-gejala sosial di masyarakat dan faktor-faktor sosial, budaya, ekonomi, berlakunya hukum di masyarakat. Suteki menyatakan $^{12}$ bahwa pendekatan socio legal berarti terdapat dua aspek. Pertama, aspek legal research, yakni objek penelitian tetap ada yang berupa hukum dalam arti norm (peraturan perundang-undangan) dan kedua socio legal, yaitu digunakannya metode dan teori ilmu-ilmu sosial tentang hukum untuk membantu peneliti dalam melakukan analisis. Pendekatan ini tetap berada dalam ranah hukum, hanya perspektif nya berbeda.

\section{PEMBAHASAN}

\section{A. Akibat Hukum Perkawinan Per- kawinan Campuran terhadap kepemilikan hak atas tanah (Harta Bersama).}

Akibat perkawinan mengenai harta benda dalam perkawinan campuran selama

${ }^{11}$ Salim HS \& Erlies Septiana Nurbani, Penerapan Teori Hukum Pada Penelitian Tesis dan Disertasi, Raja Grafindo Persada, Jakarta, 2013, hlm. 302

${ }^{12}$ Suteki dalam Leke Citra Galeria Putri, Penyimpangan Terhadap Kepemilikan Hak Atas Tanah Oleh Warga Negara Asing Melalui Perjanjian Nominee di Kabupaten Lombok Barat, Tesis, Program Studi Kenotariatan UNDIP, Semarang, 2015, hlm. 14. 
telah dilangsungkan sesuai dengan UU Perkawinan No. 1/74 dan pengaturan terhadap harta kekayaan perkawinan tersebut selanjutnya diatur pada Pasal 35 sampai Pasal 37 Undang-Undang Perkawinan Nomor 1 Tahun 1974. Harta kekayaan dalam perkawinan dilihat dari asalnya dapat dibedakan kepada 4 macam, yaitu:

1. Hartayangberasaldariwarisanatau hibah pemberian dari kerabat atau orang lain kepada suami atau isteri;

2. Harta yang berasal dari usaha suami atau isteri sebelum perkawinan;

3. Harta yang berasal dari hadiah yang diberikan kepada suami atau isteri pada waktu perkawinan;

4. Harta yang berasal dari usaha suami isteri dalam masa perkawinan.

Mengenai harta benda dalam perkawinan diatur dalam Bab VII Pasal 35 ketentuan Undang-Undang Perkawinan nomor 1 tahun 1974 sebagai berikut:

1. Harta bersama adalah harta benda yang diperoleh selama perkawinan.

2. Harta bawaan adalah harta benda yang dibawa masing-masing suami dan istri sebelumperkawinandanhartabendayang diperoleh masing-masing sebagai hadiah atau warisan.

Harta bersama dalam perkawinan dapat berupa benda bergerak (mobil, perhiasan, lukisan, emas batangan dan sebagainya) dan dapat pula berupa benda tidak bergerak berupa (tanah).

Dengan demikian harta apa saja yang (berwujud atau tidak berwujud) yang diperoleh terhitung sejak saat dilangsungkan (akad nikah) sampai pada saat perkawinan terputus, baik oleh karena salah satu pihak meninggal dunia maupun karena perceraian, maka seluruh harta tersebut dengan sendirinya menurut hukum menjadi harta bersama. Akibat perkawinan terhadap harta benda suami isteri menurut KUHPerdata adalah terjadi percampuran harta. Di dalam Pasal 119 KUHPerdata harta benda yang diperoleh sepanjang perkawinan menjadi harta bersama meliputi seluruh harta perkawinan, yaitu harta yang sudah ada pada waktu perkawinan, harta yang diperoleh sepanjang perkawinan. Mengenai percampuran harta bersama (tanah) untuk WNI yang melakukan perkawinan campuran dengan WNA telah di atur secara jelas di dalam UUPA, dalam Pasal 21 ayat (3) UUPA.

Akibat terjadinya perkawinan campuran ini maka kedudukan hak atas tanah yang mana salah satu pihak WNI tidak membuat perjanjian kawin maka dalam jangka waktu setahun harta bersama yang mereka peroleh harus dilepaskan atau jatuh ke negara, sesuai Pasal 21 ayat ( 3) UUPA. Penerapan Pasal 21 ayat (3) UUPA dalam masyarakat sesuai asas legalitas dimana hukum harus sesuai dengan penerapan aturan dalam masyarakat dilakukan setelah aturan tersebut diatur dalam peraturan perundang-undangan sehingga mengenai pengaturan hak milik WNI yang melakukan perkawinan campuran dengan WNA harus sesuai dengan pasal tersebut diatas. Lebih lanjut berkaitan dengan diatas dijelaskan dalam Pasal 58 UUPA .

Hal ini apabila seorang WNI yang menikah secara sah dengan WNA dan WNI tersebut memperoleh harta benda tidak bergerak berupa tanah dengan status Hak Milik, Hak Guna Bangunan (HGB), Hak Guna Usaha (HGU), Hak Milik atas satuan rumah susun di atas tanah HGB, baik karena pewarisan, peralihan hak melalui jual beli, hibah atau wasiat, maka dia wajib melepaskan haknya dalam jangka waktu 1 (satu) tahun sejak diperolehnya hak-hak tersebut. Pelepasan hak tersebut dengan 
cara menjual atau menghibahkan hak-hak atas tanah tersebut. ${ }^{13}$

Ketentuan tersebut dapat dikecualikan dengan adanya perjanjian kawin pisah harta yang dibuat sebelum perkawinan berlangsung tercantum dalam Pasal 29 ayat (1) UU No 1/74 Tentang Perkawinan.

Sehubungan dengan itu apabila WNI yang melakukan perkawinan campuran dengan WNA masuk agama Islam maka perjanjian kawin tersebut dilakukan secara Islam dengan membuat akta di bawah tangan, sedangkan perjanjian kawin secara perdata dibuat secara notariil yang disahkan oleh pegawai pencatat perkawinan, yaitu baik di Kantor Urusan Agama (KUA) maupun Kantor Catatan Sipil (Pasal 29 UU No. 1 tahun 1974 tentang Perkawinan). ${ }^{14}$

Berdasarkan ketentuan akibat hukum perkawinan terhadap suami-isteri, anak serta harta perkawinan tersebut diatas, adalah untuk memberikan keadilan, ketentraman serta kepastian hukum kepada suami-isteri, anak, dari harta kekayaan perkawinan demi menjamin masa depan khususnya terhadap isteri dan anak. Dalam hal ini Aristoteles dalam bukunya Rhetorica menjelaskan bahwa; ${ }^{15}$

"Kepastian hukum sangat diperlukan untuk menjamin ketentraman dan ketertiban dalam masyarakat, karena kepastian hukum mempunyai sifat sebagai berikut: a) adanya paksaan dari luar (sanksi) dari penguasa yang bertugas mempertahankan dan membina tata tertib masyarakat dengan perantara alat-alatnya; b) sifat undang-undang yang berlaku bagi siapa saja. Kepastian hukum ditujukan pada sikap lahir manusia, ia tidak mempersoalkan apakah sikap batin seseorang itu baik atau buruk, yang diperhatikan ada-

\footnotetext{
${ }^{13}$ Irma Devita Purnamasari. Op.Cit., hlm. 166.

${ }^{14}$ Ibid., hlm. 167. 46.

15 Aristoteles dalam Satjipto Raharjo. Op.Cit. hlm.
}

lah bagaimana perbuatan lahiriahnya. Kepastian hukum tidak memberi sanksi kepada seseorang yang mempunyai sikap batin yang buruk, akan tetapi yang diberi sanksi adalah perwujudan dari sikap batin yang buruk tersebut, atau menjadikannya perbuatan yang nyata ataukonkrit. Kepastian hukum secara normatif adalah ketika suatu peraturan perundang-undangan dibuat dan diundangkan secara pasti, $k a-$ rena mengatur secara jelas dan logis. Jelas dalam artian tidak menimbulkan keraguraguan (multitafsir), dan logis dalam artian menjadi suatu sistem norma dengan norma lain, sehingga tidak berbenturan atau menimbulkan konflik norma. Konflik norma yang ditimbulkan dari ketidakpastian peraturan perundang-undangan dapat berbentuk kontestasi norma, reduksi norma, atau distorsi norma". ${ }^{16}$

Dalam praktiknya, apabila kepastian hukum dikaitkan dengan keadilan hukum, maka akan kerap kali tidak sejalan satu sama lain. Adapun hal ini dikarenakan di satu sisi tidak jarang kepastian hukum mengabaikan prinsip-prinsip keadilan hukum, sebaliknya tidak jarang pula keadilan hukum mengabaikan prinsip-prinsip kepastian hukum. Apabila dalam praktiknya terjadi pertentangan antara kepastian hukum dan keadilan hukum, maka keadilan hukum yang harus diutamakan. Alasannya adalah, bahwa keadilan hukum pada umumnya lahir dari hati nurani pemberi keadilan, sedangkan kepastian hukum lahir dari suatu yang konkrit.

Undang-Undang Nomor 5 tahun 1960 tentang Peraturan Dasar Pokok-Pokok Agraria menegaskan benda tidak bergerak (tanah) dalam Pasal 21 ayat (1) bahwa, "Hanya Warga Negara Indonesia dapat mempunyai hak milik", dan dijelaskan pula pada Pasal 21 ayat (4) yaitu, "Selama

\footnotetext{
${ }^{16}$ Aristoteles dalam Satjipto Rahardjo, Ilmu Hukum , Citra Aditya Bakti, Bandung, 2000, hlm. 46.
} 
seseorang di samping kewarganegaraan Indonesianya mempunyai kewarganegaraan asing maka ia tidak dapat mempunyai tanah dengan hak milik dan baginya berlaku ketentuan dalam Pasal 21 ayat (3) UUPA." Yaitu,:

"Orang asing yang sesudah berlakunya undang-undang ini memperoleh hak milik karena pewarisan tanpa waktu atau percampuran harta karena perkawinan, demikian pula warga Negara Indonesia yang mempunyai hak milik dan setelah berlakunya undang-undang ini kehilangan kewarganegaraannya, wajib melepaskan hak itu didalam jangka waktu 1 tahun sejak diperolehnya hak tersebut atau hilang kewarganegaraan itu. Jika sesudah jangka waktu tersebut lampau hak milik itu tidak dilepaskan, maka hak tersebut hapus karena hukum dan tanahnya jatuh pada negara, dengan ketentuan bahwa hak-hak pihak lain yang membebaninya tetap berlangsung."

Selanjutnya berdasarkan Pasal 21 ayat (3) UUPA, WNA yang memperoleh hak milik karena pewarisan dan terjadinya percampuran harta akibat karena perkawinan, serta WNI karena kehilangan kewarganegaraan mengikuti suami/isteri , atau WNI yang berkewarganegaraan ganda maka para pihak perkawinan campuran tersebut harus melepaskan hak miliknya atas tanahnya dalam jangka waktu satu tahun atau jatuh ke negara.

Dengan mengikuti ketentuan Pasal 21 ayat (3) UUPA tersebut, ada timbul kesenjangan terhadap WNI yang melakukan perkawinan campuran dimana haknya sebagai warga Negara Indonesia tidak bisa sepenuhnya mendapatkan hak milik atas tanah dari percampuran harta bersama akibat perkawinan campuran tersebut. $\mathrm{Hal}$ ini ada seolah olah pertentangan norma (Conflict of norm). Atas penafsiran dari Pasal 21 ayat (3) UUPA tersebut, maka sudah tentu hak konstitusional seorang WNI akibat dari sebuah perkawinan campuran hilang. Padahal menurut UU No. 11 Tahun 2006 tentang Hak-hak Sipil, (mempertahankan hak sipilnya). UU No. 12 Tahun 2006 disebutkan bahwa perkawinan tidak boleh menyebabkan seorang kehilangan hak kewarganegaraan nya. Karena tanah merupakan sumber ekonomi sebuah keluarga, selain itu tanah juga merupakan identitas dan keterkaitan yang sangat erat bagi seorang WNI. Maka dengan adanya pembatasan sebagaimana yang dicantumkan dalam pasal 21 ayat (3) tersebut maka jelas-jelas hak seorang WNI dalam sebuah perkawinan campuran adalah sepenuhnya tergantung dari secarik kertas yang disebut perjanjian kawin.

\section{B. Penerapan Ketentuan Pasal 21 Ayat (3) Uupa Terhadap Kepemilikan Hak Atas Tanah Akibat Perkawinan Campuran.}

Pengaturan mengenai hak atas tanah didalam Pasal 4 ayat (1) UUPA yang menentukan bahwa, ${ }^{17}$ "Atas dasar hak menguasai dari negara atas tanah sebagaimana dimaksud dalam Pasal 2, ditentukan adanya macam-macam hak atas permukaan bumi, yang dapat diberikan dan dapat dipunyai oleh orang-orang lain serta baik sendiri serta badan-badan hukum. Adapun macam-macam hak atas tanah yang dimaksut dalam Pasal 4 ayat (1) tersebut diatur lebih lanjut dalam Pasal 16 dan 53 UUPA. Adapun hak-hak atas tanah yang bersifat primer adalah jenis-jenis hak atas tanah yang diatur dalam Pasal 16 ayat (1) terdiri dari:
1. Hak Milik
2. Hak Guna Usaha
3. Hak Guna Bangunan
4. Hak Pakai
5. Hak Sewa

${ }^{17}$ H.M. Arba, Op.Cit. hlm. 96-97. 


\section{Hak Membuka Tanah}

7. Hak Memungut Hasil Hutan dan hak-hak lain yang tidak termasuk dalam hak-hak tersebut di atas yang akan ditetapkan dengan undang-undang serta hak-hak yang sifatnya sementara sebagaimana disebutkan dalam Pasal 53 UUPA.

Hukum agraria nasional sesuai dengan (policy) wawasan nusantara Indonesia memandang perlu untuk mengadakan diferensiasi antara warga negara Indonesia dan warga negara asing dimana bumi, air, ruang angkasa, dan kekayaan alam Indonesia adalah milik seluruh rakyat Indonesia dan merupakan kekayaan nasional, hal ini sebagaimana tercantum dalam Pasal 1 ayat (1) dan (2) UUPA. WNI dalam hal ini lebih diprioritaskan, namun demikian diantara sesama WNI dan WNA pada prinsipnya hukum agraria nasional menjamin persamaan hak. Maksudnya, bahwa hukum agraria nasional memberikan persamaan hak dalam bidang hukum agraria kepada seluruh WNI tanpa memperhatikan apakah dia laki-laki atau wanita, apakah dia pribumi atau non pribumi, apakah dia berasal dari daerah yang satu atau dari daerah lainnya. ${ }^{18}$

Hak-hak yang bersifat sementara yang disebut dalam Pasal 53 Undang-Undang Nomor 5 Tahun 1960 tentang Peraturan Pokok-pokok Agraria dimaksudkan bahwa suatu ketika hak-hak tersebut akan ditiadakan sebagai lembaga-lembaga hukum karena Undang-Undang Pokok Agraria yang baru. Hak-hak ini terdiri dari :

1. Hak Gadai

2. Hak Usaha Bagi Hasil

3. Hak Menumpang

4. Hak Sewa Tanah Pertanian Hak Milik

Dasar hukum pengaturan hak milik diatur dalam Pasal 20 sampai dengan

${ }^{18}$ Ibid. hlm. 68.
Pasal 27 UUPA. Berdasarkan Pasal 20 ayat (1) UUPA, hak milik adalah "Hak turun temurun, terkuat, terbanyak yang dapat dipunyai orang atas tanah dengan mengingat fungsi sosial, yang dapat beralih dan dialihkan kepada pihak lain". Ketentuan dalam Pasal 6, hak milik yang terkuat dan terpenuh adalah sifat-sifat utama dari hak milik dimana hak milik dapat beralih dan dialihkan kepada pihak lain. ${ }^{19}$

Subjek hak milik berdasarkan ketentuan Pasal 21 ayat (1) bahwa subjek hak milik itu sebagai berikut: ${ }^{20}$

a. Warga Negara Indonesia; dan

b. Badan hukum yang ditetapkan oleh pemerintah sesuaidengan ketentuanyang berlaku.

\section{Efektifitas Penerapan Ketentuan Pasal 21 Ayat (3) UUPA Dalam Perkawinan Campuran.}

Prinsip nasionalitas sebagaimana tercermin dalam Pasal 1 ayat (2) UndangUndang Pokok Agraria dan lebih ditegaskan lagi dalam Pasal 21 ayat (1) UUPA yang menyatakan bahwa,"hanya warga Negara Indonesia dapat mempunyai hak milik". Sebagai suatu pengecualian, perusahaan asing yang melakukan investasi di Indonesia dapat memiliki hak atas tanah berupa Hak Guna Bangunan (HGB), Hak Guna Usaha (HGU), Hak Pakai dan Hak Sewa. Aturan bagi orang asing atau badan hukum asing yang ingin berinvestasi di Indonesia untuk dapat memiliki hak atas tanah berupa HGB, HGU, Hak Pakai, Hak Sewa dan sebagainya dipersyaratkan harus didirikan dalam bentuk Perseroan Terbatas (PT. PMA). Hal ini, sebagaimana tercantum dalam Undang-Undang Republik Indonesia Nomor 25 Tahun 2007 tentang Penanaman Modal dan juga PP No 41/1996 tentang Pemilikan Rumah Tempat Tinggal atau Hunian Orang Asing yang Berkedudukan

\footnotetext{
${ }^{19}$ Ibid. hlm. 97.

${ }^{20}$ Ibid. hlm. 97-102.
} 
di Indonesia (Lembaran Negara tahun 1996 No 58 Tambahan lembaran Negara Tahun 1996 No 58, Tambahan lembaran Negara No 3644). Berdasarkan Pasal 2 angka 2 PP No. 41 Tahun 1996 yang menyatakan bahwa "Rumah tinggal atau hunian yang dapat dimiliki oleh orang asing adalah satuan rumah susun yang dibangun diatas bidang tanah hak pakai atas tanah negara". Secara khusus peraturan perundangundangan terkait hak WNA dan badan hukum asing atas tanah beserta bangunan dapat dikelompokkan menjadi tiga yaitu:

1. Kelompok peraturan perundangundangan terkait dengan hak atas tanah beserta bangunan;

2. Ketentuan berkenaan dengan subjek hak atas tanah beserta bangunan;.

\section{Ketentuan dibidang perpajakan.}

Prinsip nasionalitas sebagaimana ditentukan dalam kedua pasal diatas, juga dapat ditemukan dalam ketentuan Pasal 21 ayat (3) UUPA. Ketentuan Pasal 21 ayat (3) UUPA tersebut jelas mencerminkan prinsip nasionalis, karena melalui pasal tersebut bertujuan agar kepemilikan, penguasaan dan pemanfaatan tanah, melalui perkawinan campuran tidak jatuh kepada orang asing (WNA). Oleh karena itu, bagi WNI yang melakukan perkawinan campuran dengan WNA atau sudah melepaskan status WNI nya, sejak satu tahun kehilangan status WNI nya maka harus melepaskan hak milik atas tanah tersebut dalam jangka waktu satu tahun atau jatuh ke negara. Ketentuan tersebut di atas, tentu berlaku bagi WNI yang melakukan perkawinan campuran. Dengan demikian, WNA tidak dibenarkan mempunyai Hak Milik. Prinsip kebangsaan yang dianut oleh UUPA No 1/1960 merupakan pembatasan secara langsung terhadap peralihan Hak Milik, yaitu berupa larangan melakukan peralihan hak kepada orang-orang yang bukan warga Negara Indonesia. ${ }^{21}$

Berikut ini akan penulis kemukakan berdasarkan informasi yang didapat hasil wawancara penulis terhadap responden dan informan yaitu:

1. Responden melangsungkan perkawinan campuran di Kab. Lombok Barat dan Kota Mataram Lombok- NTB.

2. Terdapat responden yang membuat perjanjian kawin karena mengetahui dan paham akan aturan hukum yang berlaku bila menikah dengan WNA, dimana harta bersama yang diperoleh dalam jangka waktu 1 tahun harus di alihkan atau jatuh ke negara. Sesuai ketentuan Pasal 21 ayat (3) UUPA. Kecuali dengan ketentuan lain bahwa WNI dapat memiliki hak milik atas tanah/rumah dengan mempunyai perjanjiankawin. Haliniuntuk menjamin kepastian dan perlindungan hukum hak milik atas tanah pihak WNI (anak/istri) di kemudian hari.

3. Terdapat responden yang tidak membuat perjanjian kawin, hal ini disebabkan karena ketidaktahuan dan ketidakpahaman tentang perjanjian kawin dan pentingnya membuat perjanjian kawin sebelum perkawinan berlangsung agar terjadi pemisahan harta atau menurut responden tidak perlu membuat perjanjian kawin karena pada saat mereka menikah belum mempunyai harta bersama, baik dari pewarisan juga harta bawaan berupa benda bergerak atau tidak bergerak. Dan juga ada alasan responden bahwa responden sudah memahami pentingnya membuat perjanjian kawin akan tetapi mereka sengaja tidak membuat perjanjian kawin karena menurut pandangan responden dalam kenyataannya tetap bisa memiliki hak milik atas tanah/rumah, dengan

${ }^{21}$ Munir Fuady, Hukum Bisnis Dalam Teori Dan Praktek, (Buku Ketiga) Cet, 1 Adytia Bakti, Bandung, 1994, hlm. 23. 
berbagai cara penyeludupan hukum seperti pinjam nama ( Nominee).

4. Responden sebagian juga tidak mengerti apa makna dan arti pentingnya perjanjian kawin dalam perkawinan campuran, dan bagaimana prosedurnya, kapan dibuat dan dimana membuat perjanjian kawin, dikarenakan faktor pendidikan yang kebanyakan tamatan SMP-SMU/ sederajat.

5. Semua responden yang melakukan perkawinan campuran masih memegang kewarganegaraan Republik Indonesia.

Responden tidak ada yang mencatatkan perjanjian kawin ke Kantor Dinas Kependudukan dan Catatan sipil Kab. Lombok Barat-NTB. Menurut responden hal itu tidak begitu penting atau tidak mau tahu untuk dicatatkan karena yang terpenting perjanjian kawin sudah dibuatkan secara notaril, padahal apabila tidak dicatatkan perjanjian kawin tersebut hanya berlaku bagi para pihak yang membuatnya saja. Tidak ada tercatatnya data pernikahan yang dilangsungkan di luar negeri dicatatkan di Kantor Dinas Kependudukan dan Catatan Sipil Kab. Lombok Barat. Responden ada yang mencatatkan perjanjian kawin ke Kantor Dinas Kependudukan dan Catatan Sipil Kota Mataram. Menurut responden hal itu sangat penting untuk dicatatkan karena untuk memenuhi unsur publisitas dari perjanjian kawin dengan supaya pihak ketiga mengetahui dan tunduk pada aturan dalam perjanjian kawin yang telah dibuat oleh pelaku perkawinan campuran. Tidak ada tercatat kan data pernikahan yang dilangsungkan di luar negeri dicatatkan di Kantor Dinas Kependudukan dan Catatan Sipil Kota Mataram.

Berdasarkan data yang tercatat dalam database Keimigrasian, WNI yang melakukan perkawinan campuran dengan WNA yang dilangsungkan di NTB-Lombok dan yang mengajukan permohonan perizinan keimigrasian pada Kantor Imigrasi Kelas I Mataram berjumlah 50 pasangan dengan rincian sebagaimana terlampir :

1. Adapun WNI yang melakukan pernikahan campuran dengan WNA yang dilangsungkan di luar negeri tidak ditemukan dalam database keimigrasian mengingat belum ada yang mengajukan permohonan izin keimigrasian pada Kantor Imigrasi Kelas I Mataram;

2. Perlu kami jelaskan, bahwa tugas pokok dan fungsi pencatatan pernikahan campuran bukan tugas dan fungsi Kantor Imigrasi melainkan tugas dan fungsi instansi lain, Kantor Imigrasi hanya akan merekam data pernikahan campuran dan data pemohon lainnya ketika yang bersangkutan mengajukan permohonan perizinan keimigrasian.

Berdasarkan hasil wawancara penulis dengan beberapa notaris (informan) di Kab. Lombok Barat dan Kota Mataram bahwa:

1. Alasan responden dibuatkan perjanjian kawin untuk pemisahan harta mereka masing-masing. Dengan dibuatkan perjanjian pisah harta maka tidak terjadi percampuran harta bersama karena perkawinan campuran dan bertujuan agar merekamasing-masingmemilikihakmilik terhadap harta mereka, sehingga jika ada perjanjian kawin maka pihak WNI yang melakukan perkawinan campuran dapat memiliki hak milik atas tanah atas namanya sendiri sesuai dalam Pasal 21 ayat (3) UUPA. Dan tujuannya untuk memberikan kepastian dan perlindungan hukum kepada isteri/anak terhadap kepemilikan hak atas tanah/rumah di Indonesia.

2. Menurut Notaris ada beberapa responden yang ingin dibuatkan perjanjian kawin karena ketidaktahuan sebelumnya dan jugakarenahartabersamamerekasemakin meningkat dimana pada waktu menikah belum punya tanah/rumah. Tetapi notaris menolak untuk membuatkan 
perjanjiankawin tersebutsesuai Pasal 147 KUHPerdata. Dimana perjanjian kawin dibuat sebelum perkawinan berlangsung.

3. Notaris/PPAT tidak bisa membuatkan aktajualbeli terhadap WNIyang menikah denganWNAuntukmembeliobjektanah/ bangunan dengan hak milik tanpa ada perjanjian kawin. Bilamana ada WNI mempunyai harta bersama berupa tanah/ rumah karena pewarisan, percampuran harta,kehilangankewarganegaraandalam perkawinancampuranmakadalamjangka waktu1 tahunharusdialihkan/dilepaskan atau jatuh ke negara, sesuai Pasal 21 ayat (3) UUPA.

4. Peran Notaris/PPAT merupakan ujung tombak pertama yang sangat penting dalamprosessyaratformiluntukperalihan hak atas tanah ke hak milik oleh WNI yang sudah menikah dengan WNA sesuai ketentuan dalam Pasal 21 ayat (3) UUPA sebelum diproses pendaftaran peralihan hakkeKantor BadanPertanahan Nasional (BPN). Hal ini banyak terjadi di lapangan bahwa pihak WNI ketika datang ke kantor Notaris/PPAT untuk melakukan jual beli tanah/rumah pihak WNI hanya menunjukkan Kartu Tanda Penduduk (KTP) berstatus single dalam hal ini belum menikah (padahal sudah menikah dengan WNA). Karena syarat formilnya pembeli hanya melampirkan Kartu Tanda PendudukKTP.Untukmenyiasatinyapara Notaris/PPAT meminta Kartu Keluarga (KK) dan dari situ jelas terlihat status keluarga pihak WNI .

Berdasarkan hasil wawancara penulis dengan Badan Pertanahan Nasional (BPN) di Kab, Lombok Barat dan Kota Mataram yaitu :

1. KantorBadanPertanahanNasional(BPN) tidak mengetahui dalam pendaftaran tanah bahwa WNI itu sudah menikah (melakukan perkawinan campuran) dengan WNA. BPN adalah lembaga administrasi, selanjutnya BPN tidak mempunyai kewenangan untuk mencari tahu atau menyelidiki lebih lanjut bahwa WNI itu sudah menikah dengan WNA atau tidak. Yang terpenting syarat formil administrasi pendaftaran tanah sudah dipenuhi sehingga proses peralihan hak atas tanah di BPN bisa dilakukan sesuai ketentuan (PP No 24/97) dan Perkaban No 8/2012 tentang pendaftaran tanah.

2. Peralihan hak milik kepada WNI yang telah melakukan perkawinan campuran dengan WNA tanpa disertai perjanjian kawin tidak dibolehkan. Karena pihak WNI termasuk ke dalam ketentuan Pasal 58 UU No 1/74 tentang perkawinan dan Pasal21 ayat(3)UUPA, dimanapihakWNI dapat kehilangan kewarganegaraannya, WNI yang mempunyai hak milik karena percampuran harta dari suami/isteri akibat perkawinan campuran.

Sehingga efektifitas penerapan ketentuanPasal21 ayat(3)UUPA terhadap orang asing yang memperoleh hak milik karena pewarisan, atau percampuran harta karena perkawinan serta WNI yang mempunyai hak milik atas tanah setelah berlakunya undang-undang ini kehilangan kewarganegaraannya, wajib melepaskan hak itu dalam jangka waktu satu tahun atau hak tersebut hapus karena hukum dan tanahnya jatuh pada negara, dengan ketentuan lain tidak mempunyai perjanjian kawin dilapangan tidak berjalan secara efektif disebabkan beberapa faktor dan juga karena tidak adanya peraturan baru dari pemerintah sampai saat ini yang mengatur instansi terkait mana yang berwenang untuk pelaksanaan pengambilan tanah yang jatuhkenegaradariperkawinancampuran tersebut sesuai isi Pasal 21 ayat (3) UUPA.

Akibathukumperkawinancampuran terhadap harta bersama yang diperoleh berupa tanah dari dan selama perkawinan campuran berlangsung, dimana WNI masih bisa memiliki hak milik atas tanah 
dan pihak WNA selaku pasangan nyajuga ikut menikmati nya. Atau dengan tidak mendaftarkan perkawinan campuran sehingga pihak WNI masih berstatus single dalam Kartu Tanda Penduduk (KTP). Selain permasalahan tersebut di atas, berbagai upaya dilakukan pihak WNA untuk melakukan penyelundupan hukum dengan tujuan untuk menghindar dari Pasal 21 ayat (3), yaitu salah satunya membuat perjanjian nominee (pinjam nama).

\section{SIMPULAN}

Berdasarkan hasil pembahasan permasalahan dapat diperoleh keseimpulan sebagai berikut :

1. Berdasarkan Pasal 35 ayat (1) UndangUndang No 1 tahun 1974 tentang Perkawinan, menentukan bahwa harta benda yang diperoleh selama perkawinan berlangsung menjadi hartabersama. Oleh karenaitu, secara hukum maka hartayang diperolehselamaperkawinanberlangsung termasuk dalam perkawinan campuran antara seorang WNI dengan WNA, apakah itu merupakan harta (benda) bergerak dan tidak bergerak (berupa tanah dan bangunan) menjadi harta bersama antara suami dan istri tersebut. Akibat hukum perkawinan campuran antara WNA dan WNI terhadap harta bersama, maka seorang WNA secara hukum dapat memiliki dan menguasai tanah di Indonesia melalui perkawinan campuran. Lebih lanjut Pasal 21 ayat (3) UUPA mengatur, orang asing yang sesudah berlakunya undang-undang ini memperoleh hak milik karena pewarisan tanpa wasiat atau percampuran harta karena perkawinan, demikian pula Warga Negara Indonesia mempunyai hak milik dan demikian pula warga Negara Indonesia mempunyai hak milik dan setelah berlakunya undang-undang kehilangan kewarganegaraannya wajib melepaskan hak itu didalam jangka waktu satutahunsejakdiperolehnyahaktersebut atau hilangnya kewarganegaraan itu. Jika sesudahjangkawaktutersebutlampauhak milik itu dilepaskan, maka hak tersebut hapus karena hukum dan tanahnya jatuh pada negara.

2. Pasal 21 ayat (3) UUPA, khususnya ketentuan yang terkait dengan orang asing yang memperoleh hak milik karena pewarisan, percampuran harta, WNI yang kehilangan kewarganegaraan akibat perkawinan campuran, dimana dia harus melepaskan hak itu dalam jangka waktu satu tahun sejak diperolehnya hak tersebut, berdasarkan penelitian penulis dalam kenyataannya di lapangan tidak berlaku efektif. Hal ini disebabkan karena faktor struktur hukum, faktor penegak hukum dan faktor masyarakat.

\section{DAFTAR PUSTAKA}

\section{Buku-Buku.}

Aristoteles dalam Rahardjo,Satjipto, Ilmu Hukum, Citra Aditya Bakti, Bandung, 2000.

Fuady, Munir Hukum Bisnis Dalam Teori dan Praktek, Bandung: PT. Citra Aditya Bakti, 1999.

H.M. Arba, Hukum Agraria Indonesia, Sinar Grafika, Jakarta, 2015

HS, Salim \& Erlies Septiana Nurbani, Penerapan Teori Hukum Pada Penelitian Tesis dan Disertasi, Penerbit Raja Grafindo Persada (Jakarta 2013),

HS, Salim, Teknik Pembuatan Akta (PPAT), PT Raja Grafindo Persada, Jakarta, 2016.

M. Friedman, Lawrence. Sistim Hukum Perspektif Ilmu Sosial (A Legal Sistim A Social Science Perspective). Diterjemahkan Oleh M. Khozim. (Bandung: Nusa Media, 2009),

M. Hadjon Philipus, Perlindungan Hukum 
Bagi Rakyak Indonesia (Surabaya, PT. Bina Ilmu, 1987), Hlm. 2, Dalam Salim, HS \& Erlies Septiana Nurbani. ed. Penerapan Teori Hukum Pada Penelitian Tesis dan Disertasi. Penerbit Raja Grafindo Persada (Jakarta 2013),

Purnamasari, Irma Devita, Kiat-kiat Cerdas, Mudah dan Bijak Memahami Masalah Hukum Waris,Bandung, Mizan Pustaka, 2014

Suteki dalam Leke Citra Galeria Putri, Penyimpangan Terhadap Kepemilikan Hak Atas Tanah Oleh Warga Negara Asing Melalui Perjanjian Nominee di Kabupaten Lombok Barat, Tesis, Program Studi Kenotariatan UNDIP, Semarang: 2015.

\section{Perundang-Undangan}

Undang-Undang Dasar Negara Republik Indonesia Tahun 1945

Undang-Undang Republik Indonesia Nomor 05 Tahun 1960 Tentang Undang-Undang Pokok Agraria(L. N. TAHUN 1960 NO. 104)

Undang-Undang Nomor 01 Tahun 1974 Tentang Perkawinan

Kitab Undang-Undang Hukum Perdata (KUHPerdata)

Undang-Undang Nomor 12 tahun 2006 tentang Kewarganegaraan

Undang-Undang No.7/1984), Konvensi Perlindungan Kawin (CEDAW)

Undang-Undang tentang Hak Asasi Manusia Nomor 39 tahun 1999

\section{Internet}

Aa. Sholah, http://www.caragampang.com/2014/08/pengertian-dandefinisi-tanah-menurut. html\# diunduh pada tanggal 29 Februari 2016

Http : donyminang.blogspot.co.id/2011/11/dony.html diunduh pada tanggal 2 April 2016.

Hukum-BlogSpot,http://www.tesis hukum.com/ Perlindungan Hukum menurut para ahli, diunduh pada tanggal 22 Februari 2015 pukul 12.00 